New facts, however, can be sought and they may decide the controversial issues.

\section{Peaceful Uses of Atomic Energy}

A Major symposium on the peaceful uses of atomic energy will be held in Sydney during June 2-6. The symposium is being sponsored by representatives of the universities, professional institutes, industrial firms, power authorities, Commonwealth and State departments and the Australian Atomic Energy Commission. The symposium will be a forum for the discussion of technical and scientific aspects of the peaceful uses of atomic energy. Papers will be presented by oversees scientists as well as many Australian contributors. Particular attention will be given to the part atomic energy can play in the development of Australia. There will be several public lectures and a special atomic energy exhibition, to show developments in uranium mining, research into nuclear power and the industrial uses of radioactive isotopes. Further information can be obtained from the Symposium General Secretary, A.A.E.C. Research Establishment, Private Mail Bag, Suther. land, Now South Wales, Australia.

University News :

London

DR. F. G. Fosmer, lecturer in statistics in the London School of Economics and Political Science, has been appointed to the University readership in statistical computing tenable at that School.

Manchester

THe board of Unilever has given to the Manchester College of Science and Technology $£ 21,000$ under a seven-year deed of covensint. Out of this, $£ 2,000$ is to be allocated to the staff college, the balance to be divided equally between the Chemistry and Chemical Engineering Departments.

\section{Announcements}

A Discussion on "Experimental Results with the ZETA Apparatus on Controlled Thermonuclear Reactions" will be opened by Sir John Cockeroft in the rooms of the Royal Society on February 5 at 3 p.m.

Mr. John Bunyan, Leverhulme Research Fellow, St. Mary's Hospital Medical School, Paddington, has been elected president of the Royal Microscopical Society ; he will hold office for two years.

THe Medal of the New York Academy of Medicine has been awarded to Dr. Alphonse R. Dochez for his distinguished service in medicine. After graduation from the Johns Hopkins Medical School, Dr. Dochez was appointed to the staff of the Rockefeller Institute, where, with Gillespie, he estrablished the biological classification of pneumococei into specific types. During the First World War, Dr. Dochez worked on the serological differentiation of hæmolytic streptococci causing respiratory diseases, and later devoted some years to virus studies of the common cold.

Mr. Lewis T. WRIGHT, general secretary of the Amalgamated Weavers' Association, has been appointed to the Council for Scientific and Industrial Research in succession to Mr. W. L. Heywood, who has been appointed a member of the Restrictive Practices Court. Mr. Wright is chairman of both the Production and Scientific Advisory Committees of the Trades Union Congress and is also chairman of the British Productivity Council.
DR. M. E. Foss has been appointed head of the Department of Chemistry and Metallurgy, Coventry Technical College, in succession to Dr. H. C. Smith, who has been relieved of that office in order to take up the full-time post of vice-principal of the College, of which he has been deputy-principal for the pest five years. Dr. Foss, who is vice-chsirman of the Bristol Section of the Royal Institute of Chemistry, was senior lecturer in organic chemistry at Gloucester Technical College where he had been on the staff for six years. Prior to that he was lecturer in biochemistry at Guy's Hospital Medical School.

THE sixty-third annual congress of the SouthEastern Union of Scientific Societies will be held in Reading, meeting in the University of Reading, during April 9-11. The president-elect is Prof. H. L. Hawkins. Further information can be obtained from the hon. local secretary, Mrs. A. Hasker, Clarence Lodge, 93 London Road, Reading.

The Metal Physics Committee of the Institute of Metals is organizing a one-day symposium on "Motallurgical Aspects of Semi-Conductors", to be held on February 25 at the College of Technology, Gosta Green, Birmingham. Further information can be obtained from the Secretary, Institute of Metals, 17 Belgrave Square, London, S.W.1.

THE annual general meeting of Aslib (Scottigh Branch) will be held on February 7 in the Scottish Central Library, Lawnmarket, Edinburgh. The chairman will be Dr. W. M. Curmming, and there will be lectures on "United States Information Services to Industry in the United Kingdom" by Miss Margaret Haferd, and "Scientific Information in the Modern World" by Dr. J. C. Malloch. In the afternoon there will be a symposium on "Librarians Here and There".

THE second Australian Conference in Radiation Biology will be held at the Cancer Institute, Melbourne, Australia, during December 15-19. Papers on relevant subjects are invited, and titles and a 250 -word abstract should be in the hands of the convener by July 31. Further information can be obtained from Dr. J. H. Martin, Physics Department, Cancer Institute Board, 483 Lt. Lonsdale Street, Melbourne, Victoria, Australia.

The Ministry of Agriculture, Fisheries and Food is offering the following scholarships for rural workers, or to the sons and daughters of rural workers, of seventeen years of age or more: twenty senior scholarships tenable at universitios or colleges, for degree or diploma courses in an agricultural subject or in veterinary science; and thirty junior scholarships, with six extensions for existing holders, tenable at farm institutes for one-year courses in agriculture, horticulture, dairying or poultry husbandry.

Further details and application forms (to be completed by February 28) may be obtained from the Secretary, Ministry of Agriculture, Fisheries and Food, Great Westminster House, Horseferry Road, London, S.W.1, or from education offices of County Councils.

THE International Council of Scientific Unions Secretariat has removed to a new addreas at Paleis Noordeine, The Hague, Netherlands.

ErratuM. In the communication entitled "Ántimitotic Activity of 5-Tertiary Butyl Benzimidezolone" in Nature of December 21, p. 1428, from paragraph 3 onwards, for "5-tertiary benzyl benz. imidazolone" read " 5 -tertiary butyl benzimidazolone". 